\title{
Implementation of Divorce in Bali Society Related to National Marriage Law
}

\author{
Ni Nyoman Sukerti ${ }^{1}$, I G.A.A.Ari Krisnawati ${ }^{2}$ \\ Department of Law \& Society, Faculty of Law \\ Udayana University \\ Bali, Indonesia \\ nym_sukerti@unud.ac.id
}

\begin{abstract}
This study aims to explore and analyze the implementation of divorce in the Village Pakraman Kubu, Kubu Village, Bangli. This research is socio-legal research, which relies on field data as primary data. Data were extracted by interview, then processed and analyzed qualitatively. The results show that in the last ten years there have been six divorced couples and none of this has been done before the court. Divorce is done customarily for various reasons, because it is very simple, does not understand the Marriage Law, through the court hearing takes a long time and cost more. This is due to the attitude, behavior or legal culture of the people who prefer to deviate from the national marriage law and the lack of socialization from related parties. Thus the Marriage Law has not been influential in the implementation of the divorce. The conclusion is that the divorce remains customary so the marriage law has not reflected any influence on the implementation of the divorce.
\end{abstract}

Keywords: Implementation, divorce, community, Bali, Marriage Act

\section{INTRODUCTION}

Speaking of marital matters, the conversation is nothing more than two different human beings. Where humans as social beings can not live alone without any other human assistance. Humans in life experience several phases and the most important phase is the phase of marriage because in this phase of life is actually tested by the situation and conditions. In the beginning, every married couple aims to reach a happy and harmonious household, not planning for divorce. A marriage always begins and is colored with nice and good things. Each married couple wants a smooth journey to the old phase of grandparents and finally leave this mortal world.

The passage of time, where not all married couples are fortunate to be able to undergo the marriage of the household well, but there are times when the storm of the household and finally to the level that can not be maintained or ended in divorce.

Prior to the enactment of Law no. 1 Year 1974 on Marriage (hereinafter abbreviated as Marriage Law), marriage rules are spread out in various regulations. These rules are Mixed Marriage Law, Christian Marriage Ordinance (HOCI), and Civil Code (KUHPerd), Customary Law and Religious Law. With the enactment of Marriage Law then how the existence of these rules. Marriage Law is a legal Unification in the field of marriage This means that within one territory of the state of Indonesia there is only one legal system in the field of marriage. In this regard, when examined under the provisions of Article 66, where the rules concerning such marriages as long as they are regulated are declared no longer valid. While customary law and religious law have not been regulated in the Marriage Law. This means that customary law and religious law concerning marriage still have a chance to apply. Thus in the field of marriage law is still valid more than one legal system, it is not excessive where when Hazairin said that the national marriage law is a unique legal unification.

In this study the focus of the study is the implementation of divorce after the enactment of Marriage Law in the Village Pakraman Kubu, Kubu Village, Bangli. In the area there is a very unique divorce execution, in which some couples agree to sign divorce at Pura Puseh as the Bali Post, "In Kubu Village, Bangli Six Couples Join Mass Divorce". This is chosen because the divorce procedure is very unique. Related to that uniqueness then this research becomes important done to find and get the answer.

\section{RESEARCH METHOD}

Amiruddin classified legal research into two, namely normative legal research (doctrinal) and sociological legal research (socio legal research). Related to that this research is empirical law research where field data as primary data. This study will not test the hypothesis, but will explore information as much as possible in connection with the implementation of massive divorce. The excavated data are primary data and secondary data. Primary data were 
extracted from field sources, while secondary data were obtained from tracing legal and non-legal documents containing information relevant to the study. Pimer data were extracted by interview method with interview guide, then data was processed and analyzed qualitatively and completed with situational analysis.

\section{RESULTS AND ANALYSIS}

\subsection{Results}

The Balinese people in general and especially the people of Desa Pakraman Kubu are still very respectful of customary law. In this connection, the research is about the implementation of divorce by customary law, the researcher emphasizes on Balinese customary law which of course is still upheld by almost the majority of Balinese Hindu society though the Balinese already used to live in the national and even international even. This matter can be known from not least Balinese Hindu people who interact through marriage with non-Bali citizen and even with foreign citizen (WNA) .National and global friendship does not diminish the view of Balinese society in respecting of customary law as local wisdom (local genius).

Refer to the focus of the study, it is first important to point out what exactly the divorce is. In Indonesian Dictionary mentioned that divorce is a broken relationship as a husband and wife. Divorce can be described that the breaking of marriage bond between husband and wife causes by various reasons where one with another very varied.

Marriage couple end their marriage relationship with divorce for several reasons. Related to this matter, the result of research shows as follows; because they has no child after a long marriage, feel bored with partner, and the most unique reason is the husband wanted to be a pastor (pemangku / sulinggih) but his wife disagreed, and also economic reasons, there were no reason because of domestic violence.

Above has been described that for couples who experience failure in living a happy and harmonious family life. Failure which due to the breaking up of legal relationship with divorce or marriage has been disbanded. The way that taken by the parties or husband and wife are very varied of the respondents in this study. The couples wishing to divorce are not subject to litigation or judicial bodies, it is not in accordance with the provisions of Article 39 paragraph 1 which reads as follows; "Divorce can only be done in the presence of the Court after the Court concerned and unsuccessfully reconcile both parties". The point is the Marriage Act actually complicates the occurrence of divorce by divorce before the court. Thus, the parties who want to end the marriage relationship must think more mature and mature in making decisions. The problem is the parties who want to divorce it would prefer not through the judiciary but performs customarily. Legally, such divorce remains unlawful but in relation to banjar or pakraman villagers will have an effect on their membership, as Ketut Sudantra says, that divorce according to Hindu customs and religion in Bali is still important in the customarily matters, especially regarding membership in banjar or pakraman village (such as tetegenan krama, reramon and so on). This will determine the status of banjar adat or pakraman village membership called "nyapian". In reference with the divorce procedure after the entry into force of the Marriage Law, within a period of 10 years where there have been six divorced couples, none have taken the litigation or the Court. This means that customary law is still so strongly binding the mindset of the citizens in the village of Pakraman Kubu.

\subsection{Analysis}

Before arriving at the focus of the study that is about divorce, it is necessary first to describe the meaning of marriage because of divorce must precede the existence of a marriage. Two persons with different gender will attract to live together through marriage so that marriage is very important in human life. Marriage is a legal act perpetrated by a woman with a man to foster a household and have certain legal consequences. The objective is to continuing generation for avoiding extinction. Related to that, if in a marriage is not blessed with children can lead to such acts as polygamy, appointment, and the most extreme is the breakup of marriage called divorce.

In the Marriage Law, the definition of marriage is regulated in Article 1, as for the provision as follows: marriage is a spiritual bond between a man and a woman as the husband and wife by the purpose of realizing a happy and eternal family (household) with the Faith to the God Almighty. Associated with the understanding of marriage before the enforcement of the Marriage Law, discovered by expert where one with another is different but has no different meaning.

Djaren Saragih states that the marriage is a life where two people of different sexes are a man and a woman running a life together that embodies the unity of their respective households in life as husband and wife. Such common life in everyday life has certain legal consequences. While Surojo wignjodipuro said that marriage is a very important event in the life of our society; because the marriage is not only about women and men going to the bride, but also the parents of both sides, their brothers, even their respective families. Otje Salam Soemadiningrat argues that the marriage is the implementation of the institutionalized command of God in society to form a family in family ties. On the other hand Surojo Wignjodipuro in C. Dewi Wulansari argues that marriage in customary law is believed that marriage is not only an important event for those who life, but also an important event for their already dead ancestors.

Taking into account the above understanding of marriage, marriage is very important for human life, because it is not only about women and men who are married but far more widely. This means also concerning parents, relatives, family, and even the community. With the enactment of the Marriage Law then what about the customary marriage. Related to that matter, based on the 
provisions of Article 66 of Law No.1 Year 1974 where customary law and religious law are not declared revoked. The provision of Article 66 reads: for marriage and all things related to marriage based on this law, then with the coming into effect of this law the provisions set forth in the Civil Code (Burgerlijk Wetboek), Christian Marriage Ordinance (Huwelijks Ordonantie Christen IndonesiaS.1933 No.74), Mixed Marriage Regulation (Regeling op de gemengde Huwelijken S. 1898 No. 158) and other rules governing marriage to the extent provided for in this law shall be declared void. This means that customary law and religious law have not been regulated yet still have the opportunity to remain in effect.

In every marriage, initially begins with the good things and there is no plan from each side to end his marriage with a divorce. Human may plan according to his ability but the decisive time and will of God Almighty (Ida Sanghyang Widi Waca). Where couples who initially live a happy, harmonious household life can be slammed by the inevitable storm of life, the breakup of marriage due to divorce. The marriage breakup due to a divorce can result in legal consequences resulting from ex-husband and former wife, children and consequently to their marriage property or common property.

In looking at the legal consequences of divorce, it can not be separated from the familial system adopted by the local community. In Indonesia, there are three kinship systems, namely matrilineal system, patrilineal system and paretal system, where each of the familial system in divorce has unequal legal effect for the former husband and also for the former wife as well as the result of the position of the child. This is because it is closely related to the problem of inheritance later, although it can generally be illustrated that where a former husband or former wife can remarry, while the consequences of his children is where the children will lose the affection of the parents intact, in addition the children will be nurtured by their father in the patrilineal society of the father, by the mother of the mother's environment in the matrilineal society and the child is maintained by the father or mother in which environment usually the children are more concerned with the parental society. Consequently, the property of the marriage or joint property, where the joint property can be shared by the exhusband or wife in question or dependent on the agreement.

Thus, the parties who want to end the marriage relationship must think more mature and mature in making decisions. But In fact, the parties who want to divorce would prefer not to go through the judiciary but to do it by custom. Legally, such divorce remains unlawful but in relation to banjar or pakraman villagers will have an effect on their membership, as Ketut Sudantra says, that divorce according to Hindu customs and religion in Bali is still important in the adat matters, especially regarding membership in banjar or pakraman village (such as tetrenan karma, reramon and so on). This will determine the status of banjar adat or pakraman village membership called "nyapian". Individual divorce can have an impact on the former married couples in which they want to marry in the future to make marriage certificates. If the marriage certificate is not made, it does not matter, the issue will arise if making a marriage certificate, which will state the status of each party. Therefore the divorce certificate also has an important role in the marriage breaking up. In addition, this marriage certificate is important, as proof of marriage has been registered in the Civil Registry Office, and also important for the birth certificate of children later. While the divorce certificate is important because as proof that the marriage was broken because of divorce.

Refer to divorce procedure after the enforcement of the Marriage Law, within a period of 10 years where there have been six divorced couples, none have taken the litigation or the Court. This means that the Marriage Law has no effect on the implementation of divorce at the research site. The above is reviewed by Lawrence M. Friedman's Theory of Law Systems, where law consists of three components: legal structure, legal substance and legal culture are highly relevant, as seen of the legal culture component, where divorced couples do not follow the provisions as stated in the law. This means that the mindset, attitudes or legal culture of indigenous divorced peoples (husband and wife) are violating the national marriage law provisions. Thus, practically the provisions of Article 39 Paragraph 1 of the Marriage Law are not followed by indigenous Balinese, so in the case of divorce procedures, the Marriage Law has not yet appeared to influence.

\section{CONCLUSIONS}

From the overall exposure above can be drawn the following conclusions: 1. Individual divorce is done by several couples with varying reasons such as because divorce is customarily simpler and does not cost much, do not understand the Law of Marriage, the divorce procedure through Courts is complicated and takes a lot of money and time. 2. The effect of marriage law in Pakraman Kubu village does not seem to exist in terms of divorce procedure, which can be known in the last ten years there are six cases of divorce and of that number does not exist through court proceedings. Factors that influence it are the attitudes, behavior or culture of community law and the lack of socialization of the Marriage Law from the relevant institutions

\section{ACKNOWLEDGEMENT}

Many thanks to; 1. Dean of Faculty of Law Udayana University, 2. Institute for Research and Community Service Udayana University, 3 Rector of Udayana University, for funding assistance so that this research can be done.

\section{REFERENCE}

Amiruddin, Zainal Asikin, 2008, Pengantar Metode Penelitian Hukum, PT RajaGrafindo Persada, Jakarta 
Anonim, 2015, "Di Kelurahan Kubu, Bangli Enam Pasutri Ikuti Perceraian Massal", Bali Post, 1 Nopember.

Djaren Saragih, 1980, Pengantar Hukum Adat Indonesia, Tarsito, Bandung.

Frieman, Lawrence M, 1977, Law and Society, An Introdruction, Printice Hall, New Jersey.

Muhammad, Bushar, 2003, Asas-Asas Hukum Adat, Pradnya Paramita, Jakarta.

Soemadiningrat,Otje Salman, 2002, Rekonseptualisasi Hukum Adat Kontemporer:Telaahan Kritis Terhadap Hukum Adat Sebagai Hukum Yang Hidup dalam Masyarakat, PT. Alumni, Bandung.

Sudantra, I Ketut, I Gusti Ngurah Sudiana, Komang Gede Narendra, 2011, Perkawinan Menurut Hukum Adat Bali, Udayana University Press, Denpasar.

Wignjodipuro, Surojo, 1976, Pengatar dan Asas-Asas Hukum Adat, Gunung Agung, Jakarta.

Wulansari, C. Dewi, 2010, Hukum Adat Indonesia Suatu Pengantar, Refika Aditama, Bandung.

Ter Haar, B.Zn, 1984, Asas-Asas dan Susunan Hukum Adat, terjemahan K. Ng. Subakti Pusponoto, Pradnya Paramita, Jakarta.

..., 2004, Himpunan Peraturan Perundang-undangan Perkawinan, Lintang Pustaka, Yogyakarta.

Pusat Bahasa Departemen Pendidikan Nasional, 2002, Kamus Besar Bahasa Indonesia, Edisi Ketiga, Balai Pustaka, Jakarta. 